ROCZNIKI TEOLOGICZNE

Tom LXVI, zeszyt 2 - 2019

DOI: http://dx.doi.org/10.18290/rt.2019.66.2-9

KS. ŁUKASZ PONDEL

\title{
W KIERUNKU CHRYSTOLOGII INTEGRALNEJ
}

\author{
ON A PATH TOWARDS INTEGRAL CHRISTOLOGY
}

A b s t r a c t. The fundamental task of this paper, which the author has chosen was to show that the Christology is in need of methodological and substantive transposition. For this purpose, the Author will analyze the contemporary models for Christology which dominate today, as well, as show their current inadequacy. The Author's intention will not be to contradict the current Christological approaches but to combine them against the background of the new model. The applied method will only present a sample of historical analysis of available Christological models, with its equivalents in contemporary theology and a conceptual explication of the directions of research, that require clarification and broadening of the knowledge. The culmination of this publication will be an attempt to combine available models, thus presenting an integral direction of research that respects the methods available in science.

Key words: Top Down Christology; Bottom Christology; Integral Christology.

Współczesne badania chrystologiczne bazują na wielowiekowej spuściźnie Ojców Kościoła oraz na wykładni czterech pierwszych ekumenicznych soborów. Jednak podstawowym i niezaprzeczalnie najważniejszym źródłem jest niezmiennie od początku historii zbawienia Słowo Boże spisane na kartach Pisma Świętego. Dlatego zadaniem teologa, a jeszcze bardziej chrystologa, jest stałe wydobywanie z tego podstawowego źródła, które jest skarbcem bez dna. Mimo wszystko, ówczesne badania naukowe pokazują, że konieczna jest jeszcze większa otwartość teologii na te nauki, które mówią wprost o człowieku. Dzieje się tak dlatego, że dzisiejsze spojrzenie na człowieka wymaga

Ks. dr ŁUKASZ PONDEL - Wydział Teologiczny UAM (filia w Kaliszu), ul. Złota 144, 62-800 Kalisz; adres do korespondencji - e-mail: pondelos@op.pl 
coraz bardziej integralnego ujęcia. W metodzie badawczej zamiast jednosylabowych ujęć dominuje wielowymiarowość. Konieczne jest więc pluriformistyczne ujęcie samej teologii, a przy tym chrystologii. Nie sposób dzisiaj ujmować człowieka tylko w sposób jednowymiarowy, dlatego komplementarność wszystkich nauk o człowieku jest aktualnie nieodzownym postulatem. Podobnie jest $\mathrm{z}$ chrześcijańskimi paradygmatami wiary, które ukierunkowują na ich główny Podmiot. Bóg Ojciec stanowi nie tylko treść wiary, ale podstawowy Podmiot poznania, do którego pierwszy przystęp ma właśnie teologia.

Celem niniejszej rozprawy będzie ukazanie koniecznej w chrystologii transpozycji metodologicznej. Aby móc tego dokonać niezbędne będzie spojrzenie na te modele chrystologiczne, które dominowały dotąd w teologii, od strony ich dzisiejszej niewystarczalności. Zamiarem Autora nie będzie negowanie obecnych dotąd ujęć chrystologicznych, ale ich połączenie na tle nowego modelu. Zastosowana metoda będzie próbą analizy historycznej dostępnych modeli chrystologicznych z ich odpowiednikami we współczesnej teologii oraz eksplikacją pojęciową tych kierunków badań, które są obecne w niniejszych modelach i wymagają wyjaśnienia oraz pogłębienia. Zwieńczeniem niniejszej pracy będzie próba ukazania na tle dostępnych modeli nowego kierunku badań w chrystologii, a mianowicie jej ujęcia integralnego.

\section{MODELE CHRYSTOLOGICZNE}

Każdy model naukowy, uprawiany na tle swojej epoki, zakładał te kryteria oraz narzędzia, które były powszechnie stosowane. W czasach Ojców Kościoła dominowała egzegeza Pisma Świętego, w czasach monastycznych teologia Ojców Pustyni, zaś w czasach scholastycznych i późniejszych racjonalizm filozoficzny. Konfrontacja teologii z jej różnymi ujęciami na tle konkretnych epok umożliwiła nie tylko jej zgłębienie, ale odsłoniła właściwy materiał badawczy, którym jest Jezus Chrystus, dając większą możliwość, aby mogła rozwinąc skrzydła na tyle, by stać się równoprawną nauką wobec pozostałych. Wzajemna komplementarność nauk humanistycznych „dała” teologii narzędzia, którymi dzisiaj się posługujemy. Jest jednak jedno niebezpieczeństwo, a mianowicie zbytnie akcentowanie w teologii tych nauk, które powinny jej służyć, a nie stanowić jej główny przedmiot. Zbytnia psychologiczna i socjologiczna aktywność w teologii wpływa na rozmycie podstawowych prawd wiary, co ostatecznie prowadzi do ich wyparcia przez te tezy, które początkowo miały jej służyć. W konsekwencji takie ukierunkowanie w teologii doprowadza do wyakcentowania roli ludzkiej w historii zbawienia, pomniejszając 
przy tym rolę Boga. Konieczne jest więc ciągłe przypominanie teologom, że ich podstawowym zadaniem jest nieustanne ukazywanie Boga człowiekowi, ale nie Boga, który tylko wpływa na ludzkie samopoczucie, ale tego, który kocha go bezwarunkowo. Kocha go do tego stopnia, że człowiek sam nie widzi dla siebie innej drogi, jak tylko życie według Jego przykazań. Kościół, będąc wciąż narażonym na kolejne ujęcia Osoby Jezusa Chrystusa na tle następnych epok, wypracował w teologii dwa kluczowe modele chrystologiczne: zstępujący i wstępujący, których pojęciowa eksplikacja wymaga ciągłej aktualizacji.

\subsection{Chrystologia „odgórna”, czyli zstępująca}

Szczegółowe omówienie tego modelu jest w tym miejscu zbędne z racji dostępnej literatury chrystologicznej, dlatego Autor ograniczy się do wskazania tych kierunków badań chrystologii zstępującej, które są dzisiaj niewystarczające. Chrystologia „odgórna”, inaczej zwana zstępującą, uchodzi za klasyczny model, stąd Kościół do dzisiaj upatruje w niej naturalny kierunek teologiczny.

Gerhard Ludwig Müller, w jednym ze swoich teologicznych opracowań, pt. Chrystologia - nauka o Jezusie Chrystusie 1 odnośnie do podejmowanego tematu zamieścił takie oto słowa: „Chrystologię naukową można zdefiniować jako metodyczną, systematyczną i posługującą się argumentami refleksję nad początkami, wewnętrznym rozwojem i przekazem wydarzenia Chrystusa, mającą na celu wykazanie, że Jezus, jako Chrystus (Pomazaniec Boga) jest w swej Osobie, posłaniu i ziemskiej historii, absolutnym wypełnieniem autotranscendencji każdego duchowego stworzenia, osiaggającego cel w Bogu"2. Spojrzenie Müllera oczywiście wpisuje się w kierunek rozwoju dzisiejszej chrystologii, jednak zbyt wiele w niej spekulacji. Mądre spojrzenie w chrystologii to pół sukcesu, konieczne jest jeszcze doprowadzenie człowieka do Tego, który stanowi jej centrum, sens i wypełnienie. Pojawia się więc pytanie, czy model chrystologii zstępującej wpisuje się w dzisiejsze oczekiwania stawiane teologii oraz czy współczesne tendencje „odgórne” są w stanie sprostać oczekiwaniom stawianym przed chrystologią ujmowaną integralnie?

Próbując odpowiedzieć na powyższe pytanie, warto bliżej przyjrzeć się obecnym we współczesnej chrystologii tendencjom zstępującym.

\footnotetext{
${ }^{1}$ G.L. MÜLLER, Chrystologia - nauka o Jezusie Chrystusie, tł. W. Szymona, Kraków 1998.

2 Tamże, s. 39.
} 
Gdyby w kilku prostych słowach ująć niniejszy model, byłoby to nic innego, jak myślowe schodzenie w dół - od Boga do człowieka. Pierwszym, który w teologicznym myśleniu wykazuje tendencje zstępujące, jest Joseph Ratzinger - Benedykt XVI. Zauważył, że „teologia [to] rozumiejące, trzymające się logosu (= racjonalne rozumienie pojmujące) mówienie o Bogu”3. Natomiast teologia przestaje spełniać swoje zadanie, gdy „,z zadowoleniem obraca się dookoła siebie i własnej uczoności”, a nawet „mija się [...] jeszcze bardziej ze swym powołaniem, gdy nauki «według własnych pożądań» wynajduje $(2 \mathrm{Tm} 4,3)$ i przez to podaje kamienie zamiast chleba: swą własną gadaninę zamiast słowa Bożego"5. Dlatego teologia powinna najpierw mówić o Bogu, by człowiek z całą swoją egzystencją mógł się na Nim oprzeć, czyli na tym, który stanowi prawdę, bo „tylko prawda jest dla człowieka odpowiednim gruntem, na którym może stanąč”. By móc na końcu wyznać: „Wierzę w Ciebie, Jezusa z Nazaretu, jako w sens (Logos) świata i mojego życia"7. Jezus jest nie tylko sensem świata w perspektywie kosmicznej, ale sensem każdego człowieka urzeczywistnianym co dnia. Gdyby jednak rozejrzeć się dookoła, trudno wyjść z założenia, że Jezus stanowi dla współczesnego człowieka sens jego życia. Dlatego chrystologia powinna nie tylko mówić o Jezusie jako sensie ludzkiego istnienia, ale na sposób integralny urzeczywistniać tę prawdę. Ratzinger dostrzega w chrystologii jej walor hermeneutyczny, tzn. uwypukla element sensu, który rzutuje na wszelkie aspekty najważniejszej doktryny chrześcijaństwa. Ratzinger, będąc jednocześnie wyrazicielem całej spuścizny chrystologicznej, widzi w Osobie Chrystusa „ośrodek i rozstrzygający moment całej ludzkości" ${ }^{8}$. Niniejsze ujęcie wpisuje się w naturalne poszukiwanie rozumu, tak iż ,wiara w Logos, w sensowność bytu”, odpowiada tej skłonności. Ratzinger uznaje również, że dzieje się tak dlatego, ponieważ w drugim artykule Credo transcendencja łączy się z immanencją, gdyż „Jezus Chrystus to [...] tajemnica [...] niesłychanego połączenia Logos z sarx, sensu i jednej postaci historii" ${ }^{\prime 10}$.

\footnotetext{
${ }^{3}$ J. RATZINGER, Wprowadzenie w chrześcijaństwo, tł. Z. Włodkowa, Kraków 2018, s. 76.

4 Tamże, s. 254.

5 Tamże.

${ }^{6}$ Tamże, s. 74-75.

7 Tamże, s. 79.

${ }^{8}$ A. Nossol, Per Christum et in Christo: kierunki wspótczesnej chrystologii katolickiej, „Collectanea Theologica” 45(1975), nr 4, s. 6.

${ }^{9}$ Tamże.

10 Tamże.
} 
Próby sprowadzenia chrystologii z wyżyn spekulacji do konkretnego życia podjął się szwajcarski teolog Hans Urs von Balthasar (†1988), którego chrystologię można zdefiniować jako personalistyczną kategorię miłości. Jego słynna praca Wiarygodna jest tylko miłośćc ${ }^{11}$, doczekała się wielu tłumaczeń. Chrystologia - według Balthasara - to nic innego jak tylko miłość, tak w sensie explicite, jak również w sensie implicite. W myśli teologicznej dokonał on koniecznego przełamania, tzn. przetransformował jej stronę spekulatywną (ortodoksję) na stronę praktyczną (ortopraksję). Analizując myśl chrześcijańską, rozwijaną przez teologów swoich epok, Balthasar dostrzega to jak mocno filozofia oddziaływała na myśl Kościoła. Zabiegi akomodacyjne miały na celu pogodzić myśl starożytną z nowożytnym chrześcijaństwem. Jezus był więc postrzegany jako ten, który wypełnia tęsknotę świata greckiego za boskim logosem. „Antyczny obraz świata - zauważa Balthasar - przeniknięty boskim tchnieniem, bez względu na to, czy postrzegany był bardziej po platońsku, czy bardziej po arystotelesowsku, po stoicku czy raczej po platońskoproklicku, implikował bez wątpienia wyobrażenie Boga. Był to obraz świata sakralnego, któremu, z formalnego punktu widzenia, brakowało jedynie punktu centralnego. Kiedy ten się pojawił, ujawniły się kosmiczne siły miłości, przelewające się ponad miarę w Bożej Agape"12. Spojrzenie Balthasara na Osobę Chrystusa jest tym, co $\mathrm{w}$ teologii jest kwintesencją chrystologiczną. Zadaniem chrystologii jest więc zmierzać do tego, co jest źródłem życia w Jezusie, a mianowicie do Jego bezgranicznej miłości do Ojca. Balthasar w swojej koncepcji nie ujmuje całościowo chrystologii, co zapewne nie było jego celem, ale z tej racji, że ukazuje kwintesencję chrystologii, zasługuje na uznanie i naszą uwagę.

Kolejnym teologiem zstępującym, przy którym warto się zatrzymać, jest Walter Kasper. Według niego chrystologia jest nieodłącznie związana z pneumatologią. Jest to ukłon w kierunku teologii prawosławnej, dla której pneumatologia stanowi fundament wszelkich teologicznych orzekań. Na myślenie Kaspera miała zapewne wpływ funkcja, jaką pełnił w Watykanie. Kierownictwo Papieską Radą do spraw Popierania Jedności Chrześcijan pozwoliło mu zbliżyć się tak do teologii protestanckiej, jak i do teologii prawosławnej. Kasper widzi, że najlepszą drogą do integralności chrystologicznej będzie uwolnienie chrystologii spod karbów statycznej spekulacji na rzecz dynamicznej i ożywczej roli Ducha Świętego. Ożywienie chrystologii leży i dzisiaj

\footnotetext{
${ }^{11}$ H.U. von Balthasar, Wiarygodna jest tylko miłość, tł. E. Piotrowski, Kraków 1997.

12 Tamże, s. 19.
} 
w gestii teologii, jednak największą przeszkodą nadal pozostaje chrystologia gabinetowa. Naukowa eksplikacja modeli teologicznych, które zostały wypracowane przez setki lat, jest niejednokrotnie największą przeszkodą dla teologa w jego własnym spotkaniu z Bogiem. Dlatego teologia W. Kaspera jest próbą wyzwolenia chrystologii spod więzów spekulacji, za pomocą jej większego powiązania $\mathrm{z}$ pneumatologią ${ }^{13}$.

Współczesna chrystologia coraz częściej akcentuje Jezusowe „bycie dla”, Jego radykalną proegzystencję. Takie ujęcie prezentował w swojej badawczej pracy teolog z Erfurtu Heinz Schürmann (†1999). Jego koncepcja, choć mogłoby się wydawać, że jest młoda, to jednak sięga samych początków chrześcijaństwa. Może samo stwierdzenie „proegzystencja” nie pojawiało się wcześniej, ale Jezusowe „bycie dla” już tak. Proegzystencja była dotąd naukową oceną natury Chrystusa, a od czasów Schürmanna otrzymała kształt chrystologiczny. Schürmann widział proegzystencję Chrystusa w czterech wymiarach, etapach Jego życia: Jesu pro-existentes Leben und Wirken ${ }^{14}$ („Proegzystencja życia i działalności Jezusa”), Jesu pro-existentes Sterben ${ }^{15}$ („Proegzystencja śmierci Jezusa"), Das pro-existente Wesen und das Erhöhten Herrn ${ }^{16}$ („Proegzystencja istoty i działania wywyższonego Pana”) oraz Das prae-existente Gründen der Pro-existenz ${ }^{17}$ („Preegzystencjalne uzasadnienie proegzystencji”). Proegzystencja - według Schürmanna - to istota tajemnicy Jezusa Chrystusa. Być w swej kenotycznej miłości tak istotnie wolnym od siebie i całkowicie dla drugich może Jezus wyłącznie na podstawie bezwzględnego zawierzenia woli Bożej i uprzedniego już tkwienia w Nim. Tajemnicą Jego radykalnej proegzystencji - można najkrócej powiedzieć - okazuje się zatem pierwotna ,inegzystencja” w Bogu. Bez tej ostatniej Jezus nie mógłby wypełnić swojego „urzędu” Odkupiciela, spełnić swej mocy i władzy Zbawiciela. Koncepcja Schürmanna zasługuje na uwagę może dlatego, że wymyka się modelowemu myśleniu. Proegzystencja sama w sobie zakłada dynamikę i jest do uchwycenia jedynie w taki sposób. Ludzkie życie jest dynamiczne, dlatego statyczne koncepcje nie mają siły przebicia wobec złożonej i ciągle zmiennej ludzkiej egzystencji. Koncepcja proegzystencjalna ma przyszłość chrystologiczną, dopóki nie stanie się kolejnym spekulatywnym modelem.

13 Por. W. KASPER, Jezus Chrystus, tł. B. Białecki, Warszawa 1983, s. 258.

14 Por. H. SCHÜRMANN, „Pro-existenz” als christologischer Grundbegriff, „Analecta Cracoviensia” 17(1985), s. 350-353.

15 Por. tamże, s. 353-357.

16 Por. tamże, s. 358-365.

${ }^{17}$ Por. tamże, s. 365-371. 
Historia rozwoju dogmatyki ukazuje, że jednostronne ukierunkowanie zstępujące jest dzisiaj niewystarczające. Coraz bardziej do głosu dochodziły nauki racjonalistyczne, jakie wymuszały na chrystologii odejście metodyczne od tych miejsc, które mówiły o Jezusowej boskości, na rzecz analizy historyczno-krytycznej Jego ludzkiej natury. Tym samym stawiano Jezusa na równi z innymi wyjątkowymi ludźmi, którzy pozostawili po sobie w historii niezatarty ślad. Działalność Jezusa szczególnie w tych miejscach, w których jest naznaczona cudownością, sprowadzano do mitu, podważając przy tym chrystologiczny dogmat o Wcieleniu Syna Bożego. Jednym z autorów zwalczających taki pogląd był Rudolf Bultmann $(\dagger 1976)$. W jednej ze swoich książek, pt. Jesus ${ }^{18}$, wskazał, że najlepszą drogą do demitologizacji jest niwelowanie nadprzyrodzonej natury Chrystusa na rzecz poznania ludzkiego, kim był jako człowiek ${ }^{19}$. Swoje badania sprowadzał do tych czynników, które mogły pomóc zrozumieć Jezusa w sensie psychologicznym i socjologicznym.

Krytyka Bultmanna może mieć swoje konotacje z krytyczną egzegezą niemieckiego teologa Hermanna Samuela Reimarusa ( $† 1768)$, który za punkt honoru obrał sobie zbliżenie nauki do człowieka. David Friedrich Strauss tak się o nim wypowiedział: „His great object seemed to bring science closer to life, to bring men of science nearer to men of the world" ${ }^{20}$. Może próba zbliżenia nauki do człowieka, choć w tym miejscu uchodzi za przesłankę szlachetną, ani nie pomaga chrystologii, a co najwyżej bardzo szkodzi. Spojrzenie Bultmanna, a tym bardziej Reimarusa na chrystologię musi spotkać się z naszą dezaprobatą.

Podsumowując, chrystologia - jak zauważa J. Ratzinger - powinna wpierw mówić o żyjącym Bogu, by człowiek z cała swoją egzystencją mógł się na Nim oprzeć, a to może dokonać się - kontynuuje H.U. von Balthasar - poprzez jej ciągłe zmierzanie do źródła życia w Jezusie, a mianowicie do Jego bezgranicznej miłości do Ojca, która stanowi kwintesencję chrystologii. By tak się mogło stać, konieczna jest - według W. Kaspera - większa implikacja pneumatologiczna w chrystologii, tzn. większe jej otwarcie się na ożywczą rolę Ducha Świętego.

18 R. Bultmann, Jesus, Germany 1965.

19 „Auch aus diesem Grunde ist das Interesse an der «Persönlichkeit» Jesu ausgeschaltet. Nicht etwa, weil ich aus der Not eine Tugend machen wollte. Denn freilich bin ich der Meinung, daß wir vom Leben und von der Persönlichkeit Jesu so gut wie nichts mehr wissen können, da die christlichen Quellen sich dafür nicht interessiert haben, außerdem sehr fragmentarisch und von der Legende überwuchert sind, und da andere Quellen über Jesus nicht existieren. Was seit etwa anderthalb Jahrhunderten über das Leben Jesu, seine Persönlichkeit, seine innere Entwicklung und dergleichen geschrieben ist, ist - soweit es nicht kritische Untersuchungen sind - phantastisch und romanhaft". Tamże, s. 10.

${ }^{20}$ H.S. REIMARUS, Fragments from Reimarus, tł. G.E. Lessing, London-Edinburgh 1879, s. 3. 
Najpełniej powyższe postulaty spełnia chrystologia proegzystencji, która - według H. Schürmanna - raz, że wymyka się modelowemu myśleniu, a dwa zakłada dynamikę i jest do uchwycenia jedynie w taki sposób. Chrystologia zstępująca, która zakładałaby wszystkie niniejsze postulaty, mogłaby pomóc chrystologii integralnej odkryć nowe kierunki dotąd w teologii nieznane.

\subsection{Chrystologia ,oddolna”, czyli wstępująca}

Tendencja wstępująca doczekała się mnóstwa uaktualnień, nie sposób ich wszystkich omówić, dlatego zatrzymamy się przy niektórych, tych najbardziej charakterystycznych. Niniejszy model za punkt wyjścia obrał człowieka oraz jego zdolność do spotkania z tym, który wciąż go szuka, z Odwiecznym Bogiem. Model ten jest charakterystyczny dla teologii antiocheńskiej, w której przeważała koncepcja dualistyczna, rozpatrująca dwie natury w Chrystusie. Teologia klasyczna, zstępująca, niejednokrotnie ścierała się z koncepcją wstępującą, mimo że ta druga stanowiła dla niej przeciwwagę. Wstępujące tendencje w chrystologii nie tylko ubogacały teologię, ale otwierały przed nią nowe horyzonty myślenia, tzw. świadomość horyzontalną.

Podobnie jak wcześniej, warto postawić pytanie, czy model chrystologii wstępującej jest w stanie sprostać oczekiwaniom stawianym przed chrystologią ujmowaną integralnie?

W nurcie wstępującym najbardziej charakterystyczna jest teologia Pierra Teilharda de Chardin $(\dagger 1955)$, który jako cel obrał sobie połączenie doktryny katolickiej z coraz bardziej dochodzącą do głosu w I połowie XIX w. teorią ewolucji. Jego chrystologia kosmiczna to nic innego, jak chrystogeneza, czyli czasowa i przestrzenna koncepcja rozwoju świata w jednym konkretnym kierunku. Wszystko, co dokonało się na przełomie ewolucji, zmierzało do całkowitego spełnienia w Chrystusie. Niniejsza koncepcja była próbą połączenia dwóch dróg: zstępującej z wstępującą, według której historia człowieka to nic innego, jak wstępująca antropogeneza zbiegająca się ze zstępującą chrystogenezą ${ }^{21}$. Chrystus - według Teilharda de Chardin - to „punkt Omega [...] - fizyczne centrum kosmosu oraz [przyczyna] i kres ewolucji świata zmierzającego ku jedności"22. Mimo jego wkładu w naukę z gruntownie opracowanymi koncepcjami antropogenezy ${ }^{23}$ i chrystogenezy ${ }^{24}$, jak również

${ }^{21}$ Por. A. Nossol, Per Christum et in Christo, s. 9.

22 Tamże, s. 10.

23 Zob. P. TeIlhard DE Chardin, Fenomen czlowieka, tł. K. Waloszczyk, Warszawa 1993, s. 193-207.

${ }^{24}$ Zob. tamże, s. 208-224. 
kosmogenezy ${ }^{25}$, noogenezy ${ }^{26}$ i biogenezy ${ }^{27}$, koncepcja chrystologii kosmicznej P. Teilharda de Chardin, raz że spotkała się krytyką Świętego Oficjum, a dwa mimo wszystko zbytnio koreluje z psychologizmem i socjologizmem w teologii. „Odkąd człowiek istnieje, sam dla siebie jest widowiskiem - wyznaje Teilhard de Chardin - [...] od dziesiątków stuleci patrzy tylko na siebie" ${ }^{28}$. Mimo zbytniego ewolucjonizowania w teologii, za co Teilhard de Chardin spotkał się z krytyką Kościoła, jego próba pogodzenia tendencji zstępującej z wstępującą rzuca więcej światła na koncepcję integralną.

Podobnie myślał kolejny teolog wstępujący Karl Rahner (†1984), którego chrystologia to nic innego, jak transcendentalna próba pogodzenia nowoczesności z klasyczną formułą chalcedońską ${ }^{29}$. Jego koncepcja chrystologiczna, to próba reinterpretacji tajemnicy Wcielenia ${ }^{30}$. Będąc „dzieckiem” swojej epoki, epoki fenomenologii, wiele razy dostrzegał niewystarczalność ówczesnego teologicznego języka. Do tego dochodziła coraz bardziej nasilająca się konfrontacja teologii z naukami Karla Jaspersa, z jego mitologizowaniem chrześcijaństwa i Rudolfa Bultmanna, z koncepcją odmitologizowania chrześcijaństwa przy pomocy fenomenologii Heideggera. Praca nad obiema skrajnymi koncepcjami, które zagrażały prawdziwej nauce Kościoła, skłoniła go do próby uplasowania tajemnicy Wcielenia w obecnych systemach naukowych za pomocą nowożytnego języka oraz nowożytnego postrzegania świata ${ }^{31}$. Posługując się fenomenologią, która - zaznaczmy - nie jest filozofią (systemem), ale metodą badawczą, dokonał przepracowania na nowo chrystologii. $\mathrm{W}$ toku pracy zrozumiał, że chrystologia jest ściśle powiązana $\mathrm{z}$ antropologią teologiczną, co pozwoliło mu połączyć otwartą transcendentalność ludzkiego podmiotu (wymiar wstępujący) z samoudzielaniem i samowyzbyciem się Boga (wymiar zstępujący) ${ }^{32}$. Tym spoiwem łączącym oba wymiary jest właśnie tajemnica Wcielenia. Owe zbawcze wydarzenie inkarnacji Rahner badał pod kątem implikacji antropologicznych, które są niezbędne, jeżeli mówi się

25 Zob. tamże, s. 44-50, 172-190, 225-239.

${ }^{26}$ Zob. tamże, s. 129-171.

27 Zob. tamże, s. 53-109.

28 Tamże, s. 13.

29 Por. K. Rahner, Podstawowy wyktad wiary, tł. T. Mieszkowski, Warszawa 1987, s. $171-175$.

${ }^{30}$ Por. tamże, s. 175-188.

${ }^{31}$ Por. A. Nossol, Per Christum et in Christo, s. 10.

32 Por. K. Rahner, Podstawowy wyktad wiary, s. 151; por. A. Nossol, Per Christum et in Christo, s. 11. 
o fakcie Wcielenia jako o zjednoczeniu teandrycznym. Dzięki metodzie fenomenologicznej oraz eksplikacji filozoficzno-religijnej, Bogo-człowieczeństwo Chrystusa suponuje niniejsze zjednoczenie w sposób nadprzyrodzony na każde ludzkie życie ukierunkowane na zbawienie ${ }^{33}$. Ludzka potentia oboedentialis, czyli otwartość na Boga, odniesienie a nawet orientacja zsynchronizowana z Bogiem, napotyka za każdym razem Bożą samowypowiedź sprowadzająca się do Jego każdorazowego samowyzbycia się dla człowieka na polu definitywnej kenozy. Jest to relacja, którą A. Nossol streszcza jako „radykalną otwartość w kierunku Boga oraz [jako] samodzielny przeciwstosunek do możliwej samowypowiedzi Boga" ${ }^{34}$. Dlatego Wcielenie - według Rahnera i Nossola - winno być rozumiane jako ,najwyższe urzeczywistnienie podstawowego odniesienia, jakie zachodzi pomiędzy Bogiem a duchowym stworzeniem w ogóle" 35 .

Koncepcja Rahnera, łącząca ujęcie wstępujące ze zstępującym, jest mocno zbliżona do ujęcia integralnego, jednak Rahnerowi nie chodziło o wymodelowanie na nowo chrystologii, ale o głębsze i bardziej adekwatne do współczesności ujęcie antropologii. Chrystologii nie postrzega jako osobnego modelu teologicznego, ale jako „najradykalniejsze przewyższające powtórzenie teologicznej antropologii”, a dzieje się tak dlatego, że w jego rozumieniu „możliwość stworzenia opiera się ma możliwości wcielenia"36. Koncepcja Rahnera, mimo jej teologicznej aktualności, jest jednostronna i w naszej ocenie integralnie niewystarczająca. Sam Rahner dostrzegał niewystarczalność w ujmowaniu chrystologii jako antropologii, dlatego w swoich późniejszych pismach - jak analizuje Nossol - „,bardziej [uwzględnia] teologię śmierci i zmartwychwstania Jezusa, bez której nie sposób dzisiaj myśleć o autentycznej reinterpretacji tajemnicy Chrystusa" ${ }^{37}$.

Inną koncepcją chrystologii wstępującej jest „chrystologia bez dwoistości” Piety Schoonenberga (†1999). Niniejsza koncepcja uzyskała również nazwę „chrystologia ludzkiej transcendencji”, a to dlatego, że Schoonenberg chciał wyzwolić chrystologię z sporu rozgrywającego się w niej samej na zstępującą

\footnotetext{
${ }^{33}$ Według Nossola, Rahnerowska pogoń człowieka za zbawieniem jest silniejsza od niego samego: „Istota ludzka jest stale (świadomie czy nieświadomie) w pogoni za człowiekiem absolutnego zaufania oraz absolutnego umiłowania, za dawca zbawienia jako takim w historii”. A. Nossol, Per Christum et in Christo, s. 11.

34 Tamże.

35 Tamże, s. 12.

36 Tamże.

${ }^{37}$ Tamże, s. 12-13.
} 
i wstępującą, co ostatecznie zakończyło się uplasowaniem jej wśród drugiej grupy. Chrystologia nie potrzebuje innych koncepcji, ale potrzebuje, aby pomiędzy tendencją zstępującą i wstępującą zamiast „albo, albo” wstawić „i”. Schoonenberg nie widział takiej możliwości, dlatego skupił się na analizie dogmatu chalcedońskiego. Dostrzegł, że Bóg nie był obecny Osobowo w Chrystusie, ale trwał w Nim jako „boski modus” (modalizm ${ }^{38}$ ). Interesowała go nie tyle ,chrystologia Boga-człowieka Jezusa Chrystusa”, ale „zbawcza obecność Boga w człowieku Jezusie Chrystusie" ${ }^{39}$. Chalcedońskie unum eundemque Christum Filium Dominum unigenitum, in duabus naturis inconfuse, immutabiliter, indivise, inseparabiliter agnoscendum ${ }^{40}$ nie tylko odrzucił, ale i zrelatywizował. Nie rozumiał nauki o preegzystencji, gdyż - jak twierdził - nic nie można o niej powiedzieć, dlatego odrzucił fakt, że Chrystus to jedna z Osób Bożych. Nietrudno zauważyć, że taka koncepcja nie tylko godziła w dogmat chrystologiczny, ale również w naturę Trynitarną Boga: „Ja i Ojciec jedno jesteśmy” (J 10,30). Koncepcja ta zasługuje na uwagę choćby od strony jej logicznej struktury, ale jest nie do pogodzenia pod kątem doktrynalnym.

Kolejna koncepcja wstępująca to chrystologia znaczenia Josefa Nolte, która jest odwróceniem teologii sensu Josepha Ratzingera na rzecz kategorii znaczenia. Jest to nic innego, jak tylko próba sfunkcjonalizowania, zrelatywizowania i spragmatyzowania wszelkich absolutnych roszczeń chrystologicznych, czyniąc tym samym Osobę Chrystusa faktem, obrazem, albo nosicielem znaczenia, ukazując Go jako kolejną postać, pośród wielu innych nosicieli „określonej przez miłość wolności”41. Nolte przekreślił tym samym podstawy biblijnego i kościelnego wyznania wiary w Jezusa Chrystusa ${ }^{42}$. Taka koncepcja mimo naszych dobrych chęci podważa dogmat o Boskości Syna Bożego i podobnie, jak w przypadku P. Teilharda de Chardin, jest nacechowana psychologizmem i socjologizmem.

\footnotetext{
38 Pogląd uznany za błędny przez papieża Dionizego. Zob. Dionysıus, De Trinitate et Incarnatione, w: H. DENZINGER, C. BANNWART, Enhiridion symbolorum definitionum et declarationum de rebus fidei et morum, No. 48, Friburgi Brisgoviae 1928, s. 25.

39 A. Nossol, Per Christum et in Christo, s. 13.

40 Concilium Chalcedonense, De duabus naturis in Christo, w: H. Denzinger, A. SCHÖNMETZER, Enhiridion symbolorum definitionum et declarationum de rebus fidei et morum, No. 302, Barcinone 1976, s. 108.

${ }^{41}$ Por. A. Nossol, Per Christum et in Christo, s. 8.

${ }^{42}$ Por. tamże.
} 
Podsumowując, chrystologia ciągle potrzebuje „punktu Omega”, do którego nie tylko będzie mogła zmierzać, ale który będzie stanowił jej każdorazową treść. Może się to dokonać - jak dostrzegał P. Teilhard de Chardin - na polu połączenia zstępującej chrystogenezy ze wstępującą antropogenezą, albo - jak proponuje K. Rahner - na polu antropologii teologicznej, dzięki połączeniu otwartej transcendentalności ludzkiego podmiotu (wymiar wstępujący) z samoudzielaniem i samowyzbyciem się Boga (wymiar zstępujący). Taka inklinacja zakłada więc ujęcie integralne. Nietrudno dostrzec, że nurt wstępujący jest bardziej zbliżony do ujęć integralnych, niż nurt zstępujący. Odrzucenie w chrystologii jakiejkolwiek jej koncepcji zawsze prowadzi do błędów teologicznych, np. podważenie nauki o preegzystencji zmierza nieuchronnie do relatywizacji dogmatów (P. Schoonenberg), a nawet do ich odrzucenia (J. Nolte). Konieczne jest więc pogłębione studium antropologiczne w chrystologii, pamiętając przy tym, że w centrum teologicznych zainteresowań stoi Bóg, który objawił się w Osobie swojego Syna. Stąd ludzkie wstępujące pragnienie spotkania z Bogiem ciągle potrzebuje zstępującej miłości Stwórcy do stworzenia.

\subsection{Chrystologia integralna}

Model chrystologii integralnej jest odpowiedzią na dwutorowo realizująca się historię zbawienia. Preegzystujący w Ojcu Syn zstąpił na ziemię po to, aby wywyższyć ludzką naturę i wskazać człowiekowi, że jego najważniejszym zadaniem jest podążanie drogą Bożą, a więc zbawczym powrotem marnotrawnego syna do Ojca (por. Łk 15,17-24).

Analiza dwóch wcześniejszych modeli pozwoliła zobaczyć, że nie sposób uprawiać dzisiejszej chrystologii pomijając którykolwiek z nich i nie tylko $\mathrm{z}$ racji ich wielowiekowej spuścizny, ale dlatego, że wpisują się w dwubiegunowość zbawczego planu. Stąd chrystologia integralna naturalnie zakłada dwutorowość niniejszych modeli. Takie spojrzenie było obecne w pracy badawczej Karla Bartha (†1968), którego chrystologia była nacechowana owym actualitas, czyli „kwalitatywnym rozwojem: obca [była] jej stagnacja, [była teologią] wciąż «w drodze»" ${ }^{33}$. Barth postulował, by chrystologię integralną cechował potrójny element formalny, a mianowicie: „pluriformizm, równoczesne «odgórne i oddolne» założenie wyjściowe [oraz] jej kontekst eklezjal-

43 A. Nossol, Duch Święty jako obecność Jezusa Chrystusa, „Collectanea Theologica” 50(1980), nr 3, s. 16. 
ny"44. Pluriformizm był odpowiedzią na coraz częstsze głosy, że w nauce konieczne jest ujęcie wielowymiarowe, które z jednej strony nie niweluje innych ujęć, a z drugiej ukazuje nowe kierunki myślenia. Jednoczesne ujęcie tendencji zstępującej ze wstępującą umożliwia chrystologii wewnętrzną komplementarność. Natomiast wymiar eklezjalny pozwala chrystologii otworzyć się na jej wymiar antropologiczny, poprzez głębsze studium chrystologii inkarnacyjnej. Potrójne ujęcie formalne było wynikiem procesu, jaki zachodził w myśleniu Bartha, od rozumianego „czysto wertykalnie wydarzenia Zmartwychwstania” poprzez coraz bardziej eksponowane przez niego ,wydarzenie Wcielenia”, aż po „tajemnicę pojednania” ${ }^{45}$. Niniejsze ujęcia Barthowskiej teologii są dosyć późne, biorąc pod uwagę jego wcześniejsze dzieło Der Römerbrief ${ }^{46}$, w którym jego koncepcja teologiczna jest oparta na takich pojęciach, jak diastaza (nieskończone oddalenie Boga od człowieka), krisis (ludzka reakcja na Boże „Nie”, rozumiane jako niezdolność do przekroczenia nieskończonej granicy pomiędzy Stwórcą i stworzeniem) oraz paradox (możliwość nosząca symptomy niemożliwego, np. Wcielenie, Zmartwychwstanie). Koncepcja Römerbrief, choć może wydawać się całkiem inna od tej proponowanej przez niego w późniejszych dziełach ${ }^{47}$, wpisuje się w teologiczną wizję chrystologii integralnej. Oprócz jej strony formalnej można również wyeksplikować stronę merytoryczną, na którą składa się, jako podstawa zbawcza, tajemnica Boga, która jest kluczem do zrozumienia jego chrystologii oraz „teologiczny realizm człowieczeństwa Jezusa”, Jego „dynamiczna jedność” i „paschalny wymiar” tej obecności ${ }^{48}$. Mimo że Barth nie był katolikiem (był kalwinem) jego chrystologia uchodzi za klasyczny przykład uprawiania chrystologii integralnej.

Jeden ze współczesnych teologów arcybiskup Alfons Nossol, badając Bartha, zauważył - i trudno się z tym nie zgodzić - że „nauka chrześcijańska, by móc na to miano zasłużyć, musi wyłącznie i prawdziwie we wszystkich swoich wypowiedziach być wprost czy pośrednio nauką o Jezusie Chrystusie

44 Tamże.

45 Por. tamże.

${ }^{46}$ K. BARTH, Der Römerbrief 1922, Zürich 2015.

${ }^{47}$ Zob. K. BARTH, Die christliche Dogmatik im Entwurf, Bd. 1: Die Lehre vom Worte Gottes, Prolegomena zur christlichen Dogmatik 1927, Zürich 1982; TENŻE, Prolegomena zur kirchlichen Dogmatik, w: Die kirchliche Dogmatik, Bd. 1, Tl. 1-2, Zürich 1964; TENŻE, Die kirchliche Dogmatik, Bd. 1-4, Zürich 1967.

${ }^{48}$ A. Nossol, Duch Święty jako obecność Jezusa Chrystusa, s. 18. 
jako opowiedzianym nam żywym Słowie Bożym"49. Tak ujęta nauka chrześcijańska wywołała wśród ówczesnych teologów niemałą konsternację, ponieważ zbytni radykalizm takiego spojrzenia wiązał się z chrystomonizmem, czyli z ujednoliceniem wszystkich traktatów dogmatycznych na sposób chrystologiczny ${ }^{50}$. Ich obawy były o tyle nieuzasadnione, gdyż nie wynikały z próby poznania teologii Bartha, a stały się jedynie krytyczną oceną wyrwanych z kontekstu kilku jego stwierdzeń. Dlatego pomocą okazała się rozprawa Alfonsa Nossola, pt. Chrystologia Karola Bartha ${ }^{51}$, która rzuciła wiele światła na teologię Bartha i pozwoliła przyjrzeć mu się w sposób całościowy. Barth - jak zauważa Nossol - nie dążył do ujednolicenia traktatów dogmatycznych, ale dostrzegał, że jest możliwa ich wzajemna komplementarność poprzez ześrodkowanie na Osobie i dziele Jezusa Chrystusa, Który stale otwiera przed teologią nowe horyzonty. Koncepcja Bartha nie godzi w żaden sposób w doktrynę katolicką, ale wymaga uzupełnienia. Jak zauważa A. Nossol, jednoczesne „odgórne i oddolne ujęcie” chrystologiczne wypływa z faktu, że Syn Boży stał się człowiekiem i wstąpił do Ojca, ale i tu - zastrzega teolog opolski - konieczna jest poprawka, ,iż tylko Bóg może stać się człowiekiem, a człowiek natomiast - nigdy Bogiem"52. Nossol zabiega również o większe powiązanie chrystologii z pneumatologia (podobnie jak u W. Kaspera), o gruntowniejsze przepracowanie chrystologii przednicejskiej i jej nauki o preegzystencji. Nossol dostrzega w chrystologii integralnej szansę na odnowę teologiczną. Upatruje ją w większym sprzęgnięciu chrystologii z takimi dziedzinami, jak antropologia, pneumatologia, eschatologia oraz sakramentologia. Podsumowując, jego chrystologia integralna to nic innego, jak chrystologia integralna antropologicznie ukierunkowana, w której wzajemnie uzupełniaja się chrystocentryzm zstępujący z wstępującym zwrotem antropologicznym ${ }^{53}$.

49 A. Nossol, Teocentryzm czy chrystocentryzm w wykładach teologii dogmatycznej, „Collectanea Theologica” 41(1971), nr 2, s. 19; TENŻE, Teologia na ustugach wiary, Opole 1978, s. 71.

${ }^{50}$ Zob. L. BouYer, Syn Przedwieczny, tł. W. Dzieża, P. Rak, Kraków 2000, s. 6-13.

${ }^{51}$ A. Nossol, Chrystologia Karola Bartha: wptyw na wspótczesna chrystologię katolicka, Lublin 1979.

52 A. Nossol, Duch Święty jako obecność Jezusa Chrystusa, s. 17.

53 A. Nossol, Teologia bliższa życiu, Paris 1993, s. 21. 
Chrystologia integralna potrzebuje zstępującej chrystologii sensu J. Ratzingera, która będzie jej narzędziem hermeneutycznym, potrzebuje zstępującej chrystologii, jako personalistycznej kategorii miłości H.U. von Balthasara, by odkrywać to, co jest jej kwintesencją, potrzebuje chrystologii Ducha Bożego W. Kaspera oraz potrzebuje zstępującej chrystologii proegzystencji H. Schürmanna, z jej każdorazowym „byciem dla” jako naturalnym kierunkiem teologicznym.

Także chrystologia integralna potrzebuje wstępującej chrystologii kosmicznej P. Teilharda de Chardin $\mathrm{z}$ jej ujęciem integralnym, czyli ze zstępującą chrystogenezą, która spotyka się ze wstępującą antropogenezą, a także potrzebuje chrystologii transcendentalnej K. Rahnera, z jej wstępującą transcendentalnością ludzkiego podmiotu, która napotyka zstępujące samoudzielanie i samowyzbycie się Boga, a to może zrealizować się poprzez pogłębione studium antropologiczne.

Chrystologia integralna wymaga pluriformizmu, czyli ujęcia wielowymiarowego, które nie neguje żadnej $\mathrm{z}$ dróg, a także ujęcia eklezjalnego, o które zabiegał K. Barth. Może stać się to jedynie na drodze pneumatologicznej otwartości, którą proponował A. Nossol, tak aby ortodoksja stawała się ortopraksją. Tylko wtedy chrystologia integralna będzie w sposób naturalny ukierunkowana antropologicznie.

\section{BIBLIOGRAFIA}

Balthasar von H.U., Wiarygodna jest tylko miłość, tł. E. Piotrowski, Kraków 1997.

BARTH K., Der Römerbrief 1922, Zürich 2015.

BARTH K., Die christliche Dogmatik im Entwurf, Bd. 1: Die Lehre vom Worte Gottes, Prolegomena zur christlichen Dogmatik 1927, Zürich 1982.

BARTH K., Die kirchliche Dogmatik, Bd. 1-4, Zürich 1967.

BARTH K., Prolegomena zur kirchlichen Dogmatik, w: Die kirchliche Dogmatik, Bd. 1, Tl. 1-2, Zürich 1964.

BouYer L., Syn Przedwieczny, tł. W. Dzieża, P. Rak, Kraków 2000.

Bultmann R., Jesus, Germany 1965.

Concilium Chalcedonense, De duabus naturis in Christo, w: H. DenZINGER, A. SChÖNMETZER, Enhiridion symbolorum definitionum et declarationum de rebus fidei et morum, Barcinone 1976, s. 106-109. 
Dionysius, De Trinitate et Incarnatione, w: H. DENZINGER, C. BANNwART, Enhiridion symbolorum definitionum et declarationum de rebus fidei et morum, Friburgi Brisgoviae 1928, s. 24-28.

KASPER W., Jezus Chrystus, tł. B. Białecki, Warszawa 1983.

Nossol A., Chrystologia Karola Bartha: wpływ na współczesną chrystologię katolicką, Lublin 1979.

Nossol A., Duch Święty jako obecność Jezusa Chrystusa, „Collectanea Theologica” 50(1980), nr 3, s. 5-24.

Nossol A., Per Christum et in Christo: kierunki współczesnej chrystologii katolickiej, „Collectanea Theologica" 45(1975), nr 4, s. 5-28.

Nossol A., Teocentryzm czy chrystocentryzm w wykładach teologii dogmatycznej, „Collectanea Theologica" 41(1971), nr 2, s. 15-28.

Nossol A., Teologia bliższa życiu, Paris 1993.

Nossol A., Teologia na usługach wiary, Opole 1978.

MÜLler G.L., Chrystologia - nauka o Jezusie Chrystusie, tł. W. Szymona, Kraków 1998.

RAHNER K., Podstawowy wykład wiary, tł. T. Mieszkowski, Warszawa 1987.

RATZINGER J., Wprowadzenie w chrześcijaństwo, tł. Z. Włodkowa, Kraków 2018.

ReIMARUS H.S., Fragments from Reimarus, tł. G.E. Lessing, London and Edinburgh 1879.

SCHÜRMANN H., „Pro-existenz” als christologischer Grundbegriff, „Analecta Cracoviensia” 17 (1985), s. 345-372.

TeILHARD DE Chardin P., Fenomen człowieka, tł. K. Waloszczyk, Warszawa 1993.

\section{W KIERUNKU CHRYSTOLOGII INTEGRALNEJ}

S t r e s z c z e n i e

Autor niniejszej rozprawy za swoje podstawowe zadanie obrał wykazanie, iż w chrystologii konieczna jest transpozycja metodologiczna i merytoryczna. W tym celu zostały przeanalizowane obecne we współczesnej chrystologii modele, które dotąd dominowały, jak również została wykazana ich dzisiejsza niewystarczalność. Zamiarem Autora nie było zanegowanie współczesnych ujęć chrystologicznych, ale ich połączenie na tle nowego modelu. Zastosowana metoda jest jedynie zaprezentowaniem próbki analizy historycznej dostępnych modeli chrystologicznych, z jej odpowiednikami we współczesnej teologii oraz eksplikacją pojęciową tych kierunków badań, które wymagają wyjaśnienia i pogłębienia. Zwieńczeniem niniejszej publikacji jest próba połączenia dostępnych modeli, prezentująca tym samym integralny kierunek badań respektujący dostępne w nauce metody.

Słowa kluczowe: chrystologia odgórna; chrystologia oddolna; chrystologia integralna. 